\title{
Chemical Characterisation of the Coarse and Fine Particulate Matter in the Environment of an Underground Railway System: Cytotoxic Effects and Oxidative Stress-A Preliminary Study
}

\author{
Anna Maria Spagnolo, Gianluca Ottria, Fernanda Perdelli and Maria Luisa Cristina * \\ Department of Health Sciences, University of Genoa, Italy Via Pastore, 1-16132 Genoa, Italy; \\ E-Mails: am.spagnolo@unige.it (A.M.S.); gianluca.ottria@unige.it (G.O.); perdelli@unige.it (F.P.) \\ * Author to whom correspondence should be addressed; E-Mail: cristinaml@unige.it; \\ Tel.: +39-010-353-8883.
}

Academic Editor: Paul B. Tchounwou

Received: 23 February 2015 / Accepted: 2 April 2015 / Published: 13 April 2015

\begin{abstract}
Background: Exposure to the particulate matter produced in underground railway systems is arousing increasing scientific interest because of its health effects. The aim of our study was to evaluate the airborne concentrations of $\mathrm{PM}_{10}$ and three sub-fractions of $\mathrm{PM}_{2.5}$ in an underground railway system environment in proximity to platforms and in underground commercial areas within the system, and to compare these with the outdoor airborne concentrations. We also evaluated the metal components, the cytotoxic properties of the various fractions of particulate matter (PM) and their capacity to induce oxidative stress. Method: We collected the coarse fraction $(5-10 \mu \mathrm{m})$ and the fine fractions $(1-2.5 \mu \mathrm{m} ; 0.5-1 \mu \mathrm{m} ; 0.25-0.5 \mu \mathrm{m})$. Chemical characterisation was determined by means of spectrometry. Cytotoxicity and oxidative stress were evaluated by 3-(4,5-dimethylthiazol-2-yl)-2,5-diphenyltetrazolium bromide (MTT) assay and Reactive Oxygen Species (ROS) assessment. Results: The concentrations of both $\mathrm{PM}_{10}$ and $\mathrm{PM}_{2.5}$ proved to be similar at the three sampling sites. Iron and other transition metals displayed a greater concentration at the subway platform than at the other two sites. The $2.5-10 \mu \mathrm{m}$ and 1-2.5 $\mu \mathrm{m}$ fractions of PM from all three sampling sites determined a greater increase in ROS; the intensity of oxidative stress progressively declined as particle diameter diminished. Moreover, ROS concentrations were correlated with the concentrations of some transition metals, namely $\mathrm{Mn}, \mathrm{Cr}, \mathrm{Ti}, \mathrm{Fe}, \mathrm{Cu}, \mathrm{Zn}, \mathrm{Ni}$ and Mo. All particulate matter fractions displayed lower or similar ROS values between platform level and the outdoor
\end{abstract}


air. Conclusions: The present study revealed that the underground railway environment at platform level, although containing higher concentrations of some particularly reactive metallic species, did not display higher cytotoxicity and oxidative stress levels than the outdoor air.

Keywords: underground railway; airborne particulate matter; metallic components; ROS

\section{Introduction}

Several epidemiological studies have demonstrated that airborne particulate matter is responsible for serious health effects, especially in urban areas. Specifically, fine and ultrafine particles are associated with acute and long-term effects such as cancer and cardiovascular disease [1-3].

A report from the prospective Cancer Prevention II study of the American Cancer Society, involving about 500,000 participants, showed that each $10 \mu \mathrm{g} / \mathrm{m}^{3}$ increase in fine particulate matter (PM) air pollution was associated with a $6 \%$ increase in all-cause mortality, a $9 \%$ increase in the risk of cardiopulmonary mortality and a $14 \%$ increase in the risk of lung cancer [4,5].

Exposure to the particulate matter produced in underground railway systems is arousing increasing scientific interest on account of the high $\mathrm{PM}_{10}$ and $\mathrm{PM}_{2.5}$ concentrations reached and their particular chemical composition, which, together with the size, markedly conditions their effect on health [6].

Very high levels of PM have been found in the underground systems of many cities $[1,7,8]$, despite the fact that the trains are electrically powered. In a study by Johansson et al. [9] the concentrations of $\mathrm{PM}_{10}$ and $\mathrm{PM}_{2.5}$ measured over a period of two weeks in the Stockholm underground displayed mean values of 470 and $260 \mu \mathrm{g} / \mathrm{m}^{3}$, respectively. These values were 5- and 10-fold higher than those measured in one of the streets with the heaviest traffic in the center of Stockholm. Moreover, Aarnio et al. [10] found that $\mathrm{PM}_{2.5}$ levels in underground stations were six times higher than those measured in an urban control environment. In addition, Adams et al. [11] evaluated the exposure to $\mathrm{PM}_{2.5}$ of commuters who travelled by various means of transport, and found levels of exposure from 3 to 8 times higher among those who used the underground than among those who used surface transport (bicycle, bus, car).

The main chemical constituents of the particulate matter found in underground systems are metals-particularly $\mathrm{Fe}$ and $\mathrm{Si}$ - and, at lower concentrations, $\mathrm{Mn}, \mathrm{Co}, \mathrm{Ni}, \mathrm{Mo}, \mathrm{Cd}, \mathrm{Cr}, \mathrm{Cu}$, $\mathrm{Ca}, \mathrm{K}[7,10,12-16]$.

Recently, several studies have aimed to determine the cyto-genotoxic action of underground PM [7,11,14,17,18], which, to date, has chiefly been attributed to the metallic components bound or adsorbed onto particles, [17,19] particularly transition metals, which are able to induce the formation of reactive oxygen species (ROS) [17,20,21]. ROS are involved in a range of mechanisms that cause lipid peroxidation of the membranes and oxidative damage to DNA. Indeed, it has been proposed that oxidative stress may initiate a specific sequence of cellular responses. At lower levels of oxidative stress, antioxidant enzymes are activated in order to protect the lung. If this antioxidant response of the cell fails to provide protection against the generation of ROS, an inflammatory response may be 
induced to attract inflammatory cells to the site of "injury". Finally, at toxic levels, cell death occurs through both apoptosis and necrosis [22].

Karlsson et al. [23] have shown that the airborne PM present in underground railway systems can cause four times more oxidative stress and eight times more damage to DNA in cells of the respiratory epithelium than the particulate matter found in the outdoor environment.

To date, no research has been carried out into the metallic composition, the cytotoxic effects and the capacity to induce oxidative stress of sub-fractions of the fine PM present either in proximity to the railway tracks or at other locations, such as commercial premises, inside underground systems. At these latter locations, both shop staff and potential customers spend considerably more time than passengers in transit; they are therefore more exposed to any contaminants that may be present in the air.

The aim of our study was to evaluate the airborne concentrations of $\mathrm{PM}_{10}$ and some sub-fractions of $\mathrm{PM}_{2.5}$ in the underground railway system environment — not only in proximity to platforms but also in underground commercial areas within the system — of a northern Italian city and to compare these with the concentrations measured outdoors at street level. We also evaluated the metallic component (transition metals and crustal elements), the cytotoxic properties of the various fractions of particulate matter and their capacity to induce oxidative stress.

\section{Materials and Methods}

The underground railway system examined was built in the early 2000s. The station where sampling was conducted handles the highest passenger throughput of the entire underground system considered and its platforms are located about $20 \mathrm{~m}$ below street level. The platforms run along both sides of the track and are long enough to accommodate trains made up of three carriages. Some of the carriages are first-generation and have a mixed (electro-dynamic and electro-hydraulic) braking system, while others are second-generation, with a full disc-brake system that is rheostatic up to a speed of $12 \mathrm{Km} / \mathrm{h}$ and mechanical at higher speeds. On working days, trains pass through every 3-4 min. The underground commercial premises monitored are located at an intermediate depth between street level and platform level. The outdoor sampling site is situated at street level, on station property just outside the station entrance/exit, and looks out onto a city center street used by traffic.

\subsection{Sampling of Airborne Particulate Matter Material}

We conducted preliminary airborne PM monitoring campaigns in the underground environments of the station (platform and commercial-intermediate area) in order to establish the duration of sampling needed to collect enough material for the various analyses. In this preliminary phase, the samples collected underwent only chemical characterisation. Tests were carried out on these samples in order to detect not only metals, but also IPA (benzo(a)pyrene, benzo(e)pyrene, nitropyrene) by means of gas chromatography-mass spectrometry (GC-MS); the latter pollutants, together with cadmium and cobalt, were never detected in these environments and were subsequently eliminated from the panel of parameters to be investigated in the study.

Air sampling was carried out on working days over a period of two weeks by means of samplers made up of a cascade impactor (SKC Inc., Eighty-Four, PA, USA) connected by means of a tube to a 
battery-driven pump (Leland Legacy ${ }^{\circledR}$ pump, SKC Inc., Eighty-Four, PA, USA). The impactor is equipped with four collector plates able to collect the coarse fraction and the fine fraction (further broken down into three sub-fractions) of the PM, which are deposited on Teflon filters (Fluoropore ${ }^{\odot}$ membrane Filters, Millipore, Darmstadt, Germany) inserted into the four zones of the impactor. The following particulate matter fractions were separated: $2.5-10 \mu \mathrm{m}$ (stage A), 1-2.5 $\mu \mathrm{m}$ (stage B), $0.5-1 \mu \mathrm{m}$ (stage C), and 0.25-0.5 $\mu \mathrm{m}$ (stage D).

During the complete monitoring campaign, the results of which are reported in the present paper, air sampling was carried out simultaneously at the three sites: the underground station platform (Site 1), about $1 \mathrm{~m}$ from the track, an intermediate underground area located immediately above Site 1 and utilized for commercial activities (Site 2), and a street-level outdoor environment located above Site 2 (Site 3) on station property just outside the station entrance/exit.

Cumulative sampling was carried out for a total of $50 \mathrm{~h}$ at Sites 1 and 2, while in the outdoor urban environment sampling was limited to $31 \mathrm{~h}$, as the filters became clogged over longer times. Air was aspirated at a flow rate of $9 \mathrm{~L} / \mathrm{min}$, a total of $27 \mathrm{~m}^{3}$ being aspirated at Sites 1 and 2 and $16.74 \mathrm{~m}^{3}$ at Site 3. Each filter underwent gravimetric analysis by means of an analytical scale with a precision of $\pm 0.01 \mathrm{mg}$, in temperature- and relative humidity-controlled conditions. The final concentration of the particulate matter material was obtained by dividing the mass of the particulate matter collected by the volume of air sampled. After weighing, the Teflon filters were cut in half; one half underwent chemical analysis, while the other underwent in vitro cytotoxicity testing and ROS determination.

\subsection{Chemical Analysis: Determination of the Concentrations of Metals}

The coarse and fine particulate matter material collected underwent chemical characterisation. Specifically, some metals known to be typically present in PM in underground systems such as magnesium, potassium, titanium, chromium, aluminium, calcium, manganese, iron, nickel, copper, zinc, molybdenum and barium were sought.

These metals were determined by means of spectrometry, which was preceded by digestion of the sample with hot concentrated acid in order to dissolve the metals associated to the particulate matter. Specifically, the sample was mineralised by adding $4-5 \mathrm{~mL}$ of a mixture of nitric acid and hydrogen peroxide (ratio 3:1) in a microwave digester at a maximum temperature of $200{ }^{\circ} \mathrm{C}$ for $15 \mathrm{~min}$. The solution yielded by digestion was recovered, filtered through $0.45 \mu \mathrm{m}$ polyvinyl fluoride (PVDF) filters and brought to a final volume of about $20 \mathrm{~mL}$.

The concentrations of the various metals were determined by means of inductively coupled plasma-optical emission spectrometry (ICP-OES) in the case of $\mathrm{Mg}, \mathrm{K}, \mathrm{Ca}, \mathrm{Fe}, \mathrm{Mn}, \mathrm{Zn}$ and inductively coupled plasma-mass spectrometry (ICP-MS) in the case of $\mathrm{Al}, \mathrm{Ti}, \mathrm{Cr}, \mathrm{Ni}, \mathrm{Cu}, \mathrm{Mo}, \mathrm{Ba}$.

\subsection{Evaluation of Cytotoxicity and Oxidative Stress}

The following tests were carried out: toxicity assessment, 3-(4,5-dimethylthiazol-2-yl)-2,5diphenyltetrazolium bromide (MTT) assay and ROS assessment. The samples were tested in triplicate in each experiment.

The portions of the filters assigned to these evaluations had previously been prepared in order to enable the particulate matter to be extracted by means of the technique described by Karlsson et al. [23]. 


\subsubsection{Cell Culture}

NCI-H727 cells derived from a non-small cell lung carcinoma of a 65-year-old Caucasian woman (ATCC, Rockville, MD, USA) were cultured as monolayers in RPMI (Roswell Park Memorial Institute) medium with $2 \mathrm{mM}$ L-glutamine (Invitrogen Gibco, Milan, Italy) and supplemented with $10 \%(\mathrm{v} / \mathrm{v})$ fetal calf serum (FCS), $100 \mathrm{IU} \cdot \mathrm{mL}^{-1}$ penicillin and $100 \mu \mathrm{g} \cdot \mathrm{mL}^{-1}$ streptomycin. Cells were grown in $25 \mathrm{~cm}^{2}$ culture flasks in a humidified $5 \% \mathrm{CO}_{2}$ atmosphere at $37{ }^{\circ} \mathrm{C}$ and were supplied with fresh culture medium every $48 \mathrm{~h}$. When $80 \%-90 \%$ confluence was obtained, the monolayers were subcultured.

\subsubsection{Toxicity Assessment}

Preliminarily, in order to identify sub-toxic particulate matter doses, i.e., unable to cause the death of over $30 \%$ of cells, cytotoxicity was assessed by means of a colorimetric method using a $1 \%$ crystal violet solution. To this end, exponentially growing cells were seeded in 96-well microtiter tissue culture plates $\left(1 \times 10^{4}\right.$ cells/well $)$ and incubated in complete medium. After $24 \mathrm{~h}$, the medium was replaced with fresh medium $(100 \mu \mathrm{L})$ containing $2 \% \mathrm{FCS}$ and $70 \mu \mathrm{g} / \mathrm{mL}$ of the different PM fractions, using 8 wells per dose. After 3, 6, and $24 \mathrm{~h}$ of incubation, the cell monolayers were rinsed three times with phosphate buffered saline (PBS), fixed with $2.5 \%$ glutaraldehyde for 10 min, stained with crystal violet, and dried. The dye taken up by the cells was solubilized in dimethyl sulfoxide (DMSO) $(100 \mu \mathrm{L} /$ well), and absorbance was read at $590 \mathrm{~nm}$ by using a microtiter plate reader (Multiskan FC M Medical, Milan, Italy). The values obtained at each dose were converted to percentage viability by comparison with a negative control (100\%).

\subsubsection{MTT Assay}

Cell viability was assessed by means of the MTT assay, which is based on the reduction of the dye MTT to formazan crystals, an insoluble intracellular blue product, in functional mitochondria of living cells. Briefly, exponentially growing cells that had reached $80 \%$ confluence in the monolayer were dissociated and seeded in 96-well microtiter tissue culture plates $\left(1 \times 10^{4}\right.$ cells per well $)$ and incubated in complete medium. After $24 \mathrm{~h}$, the complete medium was replaced with fresh medium $(100 \mu \mathrm{L})$ containing 2\% FCS and PM solutions at a concentration of $70 \mu \mathrm{g} / \mathrm{mL}$ for $6 \mathrm{~h}$. After treatment, the medium was removed and the monolayer was washed with PBS solution ( $\mathrm{pH} 7.4)$ containing $10 \mathrm{mM}$ D-glucose. The MTT solution $(0.5 \mathrm{mg} / \mathrm{mL})$ was added, and the plates were incubated for $3 \mathrm{~h}$ at $37{ }^{\circ} \mathrm{C}$ in $5 \%$ of $\mathrm{CO}_{2}$. Subsequently, the supernatant was discarded and $100 \mu \mathrm{L}$ of DMSO was added to detect MTT reduction.

The absorbance of each well was determined by a microplate reader (Multiskan FC M Medical- Milan) at $570 \mathrm{~nm}$ wavelength. Means and standard deviations of absorbance were calculated for each group and referred to sham-treated cells, the value of these latter being considered $100 \%$ viability. Results were analyzed by means of one-way ANOVA. 


\subsubsection{Reactive Oxygen Species Assessment}

H727 cells were seeded in 96-well plates at a concentration of $1 \times 10^{4}$ per well and allowed to adhere for at least $18 \mathrm{~h}$. Cells were then washed with PBS and incubated in RPMI with 2\% FCS; PM solutions were then added at a concentration of $70 \mu \mathrm{g} / \mathrm{mL}$ and the mixture was left to stand for $3 \mathrm{~h}$.

In accordance with Shuka et al. [24], dichlorofluorescein diacetate (DCFDA) was added after incubation with PM solutions. Specifically, DCFDA at concentration of $20 \mu \mathrm{M}$ was added to the medium, and incubation was continued for an additional $30 \mathrm{~min}$; cells were then washed with PBS.

The increase in oxidative stress was assessed by fluorometric analysis as depicted by fold changes in MFI (mean fluorescence intensity) values of DCFDA in comparison with the untreated cells. The emission value was recorded at $495 \mathrm{~nm}$ Ex and $530 \mathrm{~nm}$ Em by means of a fluorescence plate reader (Tecan-Infinite ${ }^{\circledR}$, Männedorf, Switzerland). Emission values were normalized by protein concentration in each well.

\subsection{Statistical Analysis}

Statistical analysis of the data was performed by means of Stata SE9 ${ }^{\mathrm{TM}}$ software (Stata, College Station, TX, USA), using the $t$-test, ANOVA and Spearman Correlation test.

\section{Results}

\subsection{Concentrations of Airborne Particulate Matter and of the Metallic Component}

Figure 1 reports the airborne concentrations of coarse and fine (broken down into sub-fractions) particulates at the three sites considered. Coarse $(2.5-10 \mu \mathrm{m})$ particulate matter (fraction A) displayed the highest concentrations, particularly at Sites 1 (platform) $\left(25.93 \mu \mathrm{g} / \mathrm{m}^{3}\right.$ ) and 3 (outdoor environment) $\left(23.30 \mu \mathrm{g} / \mathrm{m}^{3}\right)$.

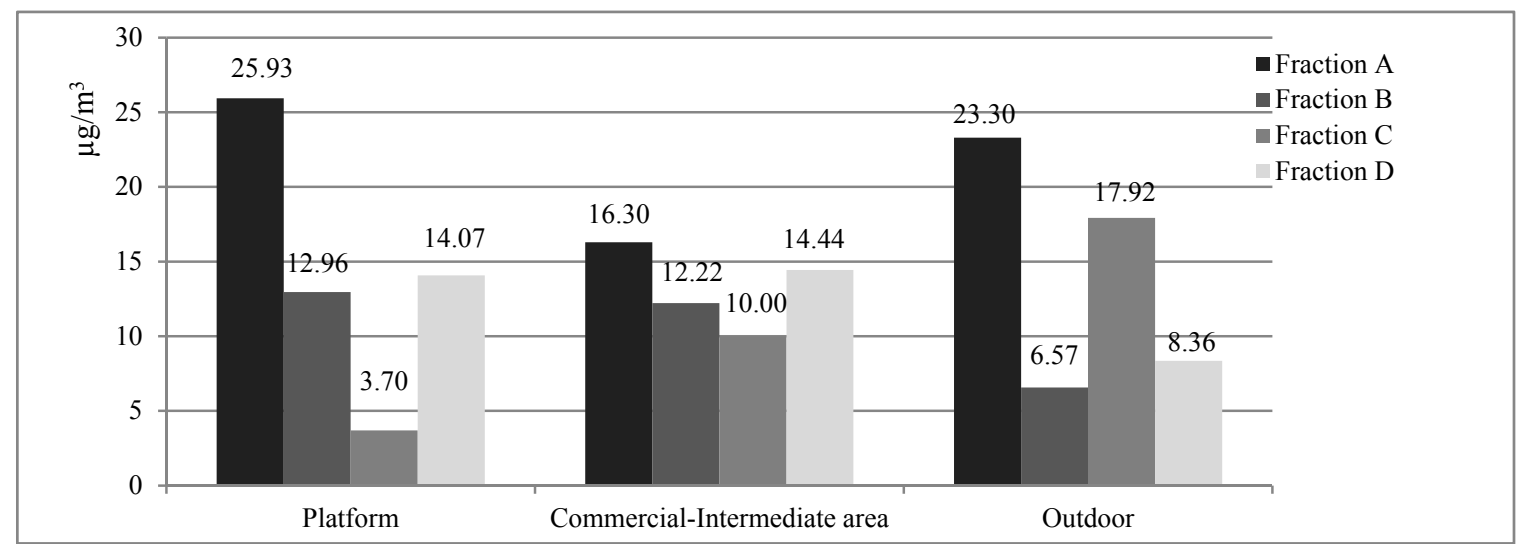

Figure 1. Concentrations $\left(\mu \mathrm{g} / \mathrm{m}^{3}\right)$ of coarse (fraction A: $2.5-10 \mu \mathrm{m}$ ) and fine (fraction $\mathrm{B}$ : 1-2.5 $\mu \mathrm{m}$; fraction $\mathrm{C}: 0.5-1 \mu \mathrm{m}$; fraction $\mathrm{D}: 0.25-0.5 \mu \mathrm{m}$ ) airborne particulate matter at the three sampling sites. 
Table 1. Concentrations $\left(\mathrm{ng} / \mathrm{m}^{3}\right)$ of transition metals and crustal elements in the various fractions of particulate matter (A, B, C, D) collected at the three sites considered.

\begin{tabular}{|c|c|c|c|c|c|c|c|c|c|c|c|c|c|}
\hline & & \multicolumn{3}{|c|}{$\begin{array}{c}\text { Fraction A }(2.5-10 \mu \mathrm{m}) \\
\left(\mathrm{ng} / \mathrm{m}^{3}\right)\end{array}$} & \multicolumn{3}{|c|}{$\begin{array}{c}\text { Fraction B }(1-2.5 \mu \mathrm{m}) \\
\left(\mathrm{ng} / \mathrm{m}^{3}\right)\end{array}$} & \multicolumn{3}{|c|}{$\begin{array}{c}\text { Fraction C }(0.5-1 \mu \mathrm{m}) \\
\left(\mathrm{ng} / \mathrm{m}^{3}\right)\end{array}$} & \multicolumn{3}{|c|}{$\begin{array}{c}\text { Fraction D }(0.25-0.5 \mu \mathrm{m}) \\
\left(\mathrm{ng} / \mathrm{m}^{3}\right)\end{array}$} \\
\hline \multicolumn{2}{|c|}{ Elements } & & Commercial- & & & Commercial- & & & Commercial- & & & Commercial- & \\
\hline \multirow{8}{*}{$\begin{array}{l}\text { Transition } \\
\text { metals }\end{array}$} & $\mathrm{Cr}$ & 15.78 & 3.11 & 5.98 & 3.23 & 2.07 & 2.18 & 1.87 & 0 & 1.31 & 0 & 0 & 1.47 \\
\hline & $\mathrm{Cu}$ & 14.22 & 13.28 & 12.41 & 12.46 & 6.36 & 4.64 & 4.49 & 2.06 & 0.74 & 2.67 & 6.40 & 0.86 \\
\hline & $\mathrm{Fe}$ & 545.34 & 244.47 & 117.15 & 212.01 & 148.99 & 115.30 & 70.79 & 33.77 & 30.94 & 30.54 & 28.65 & 32.75 \\
\hline & $\mathrm{Mn}$ & 8.60 & 3.57 & 3.23 & 2.71 & 1.94 & 2.76 & 1.58 & 0 & 0 & 1.08 & 0 & 0 \\
\hline & Mo & 10.75 & 11.00 & 0 & 9.19 & 2.90 & 0 & 0 & 0 & 0 & 0 & 0 & 0 \\
\hline & $\mathrm{Ni}$ & 2.96 & 1.74 & 0 & 2.20 & 1.12 & 0 & 0 & 0 & 0 & 0 & 0 & 0 \\
\hline & $\mathrm{Ti}$ & 15.57 & 4.67 & 12.44 & 9.58 & 2.40 & 3.73 & 2.59 & 1.82 & 3.25 & 3.02 & 1.69 & 2.81 \\
\hline & $\mathrm{Zn}$ & 7.73 & 6.87 & 15.15 & 6.98 & 4.98 & 6.07 & 3.49 & 3.64 & 5.64 & 3.01 & 2.93 & 5.77 \\
\hline \multirow{5}{*}{$\begin{array}{l}\text { Crustal } \\
\text { elements }\end{array}$} & $\mathrm{Al}$ & 89.14 & 58.91 & 67.40 & 64.73 & 35.42 & 39.57 & 26.53 & 4.45 & 5.18 & 25.03 & 5.37 & 2.15 \\
\hline & $\mathrm{Ba}$ & 122.12 & 77.75 & 64.78 & 95.68 & 75.82 & 51.32 & 98.98 & 82.42 & 48.62 & 99.16 & 84.54 & 55.78 \\
\hline & $\mathrm{Ca}$ & 1568.17 & 205.33 & 300.57 & 256.37 & 135.70 & 67.86 & 57.60 & 38.22 & 75.99 & 30.40 & 49.19 & 55.70 \\
\hline & K & 26.29 & 73.62 & 80.19 & 10.63 & 37.43 & 68.57 & 6.97 & 27.31 & 65.62 & 5.28 & 26.54 & 59.60 \\
\hline & $\mathrm{Mg}$ & 38.93 & 23.21 & 201.81 & 9.71 & 12.54 & 39.36 & 2.32 & 3.59 & 56.44 & 4.57 & 0.50 & 21.47 \\
\hline
\end{tabular}


With regard to the sub-fractions of fine particulate matter, sub-fractions B $(1-2.5 \mu \mathrm{m})$ and D $(0.25-0.5 \mu \mathrm{m})$ displayed similar concentrations at Sites 1 and 2 (commercial-intermediate area) and diminished to just above half these levels in the outdoor environment. By contrast, sub-fraction $\mathrm{C}(0.5-1 \mu \mathrm{m})$ was seen to increase from Site 1 to Site 2 and from Site 2 to Site 3.

The concentrations of $\mathrm{PM}_{10}$ proved to be $56.66 \mu \mathrm{g} / \mathrm{m}^{3}$ on the station platform, $52.96 \mu \mathrm{g} / \mathrm{m}^{3}$ in the commercial-intermediate area and $56.15 \mu \mathrm{g} / \mathrm{m}^{3}$ in the outdoor environment. Similarly, the concentrations of $\mathrm{PM}_{2.5}$ were $30.73 \mu \mathrm{g} / \mathrm{m}^{3}$ on the station platform, $36.66 \mu \mathrm{g} / \mathrm{m}^{3}$ in the commercial-intermediate area and $32.85 \mu \mathrm{g} / \mathrm{m}^{3}$ in the outdoor environment.

Table 1 shows the chemical determination results. At each monitoring site, the concentration of each of the transition metals considered tended to diminish, more or less markedly according to the metal species, as the size of the particulate matter diminished. Moreover, the coarse fraction of the particulate matter collected at Site 1 (platform) was seen to contain a higher concentration of each metal, except for zinc and molybdenum, than both the coarse particulate matter collected at the other two sites and the fine fractions from the other sites.

Each of the four fractions, with the exception of the smallest (D), displayed a greater concentration of iron at Site 1 than at the other two sites. This trend was particularly evident with regard to the coarse fraction of particulate matter, in which the concentration of iron at Site 1 reached $545.34 \mathrm{ng} / \mathrm{m}^{3}$; among all the transition metals considered, this was the highest concentration detected. The iron concentration at Site 2 (commercial-intermediate area) displayed a value that was intermediate between those recorded at Sites 1 and 3 .

With very few exceptions, the "crustal" elements, together with iron, displayed higher concentrations than the other elements analysed; this trend was observed in the various fractions considered, especially the less fine fractions, and at all sites. The element detected at the highest concentration was calcium in the coarse fraction (A) at Site $1\left(1568.17 \mathrm{ng} / \mathrm{m}^{3}\right)$. This element also displayed a higher concentration than the other elements detected in fraction $\mathrm{A}$ at Site 3 $\left(300.57 \mathrm{ng} / \mathrm{m}^{3}\right)$, in fraction B at Site $1\left(256.37 \mathrm{ng} / \mathrm{m}^{3}\right)$ and in fraction C at Site $3\left(75.99 \mathrm{ng} / \mathrm{m}^{3}\right)$ (Table 1).

\subsection{Cytotoxic and Oxidative Stress Evaluation}

\subsubsection{MTT Assay}

Figure 2 shows the MTT reduction in $\mathrm{H} 727$ cells after $6 \mathrm{~h}$ of exposure to the environmental samples. The PM collected at street level was far more cytotoxic than that collected in either the commercial-intermediate area or on the platform. In addition, only the PM components with a diameter less than $2.5 \mu \mathrm{m}$ were able to determine a statistically significant reduction in cellular activity $(p<0.01)$ in both B3 and C3 samples and a highly significant reduction in D3 $(p<0.001)$. The environmental solution obtained by sampling in Site 1 showed a low decrease of viability in all samples tested $(p<0.05)$ apart B1 sample. 


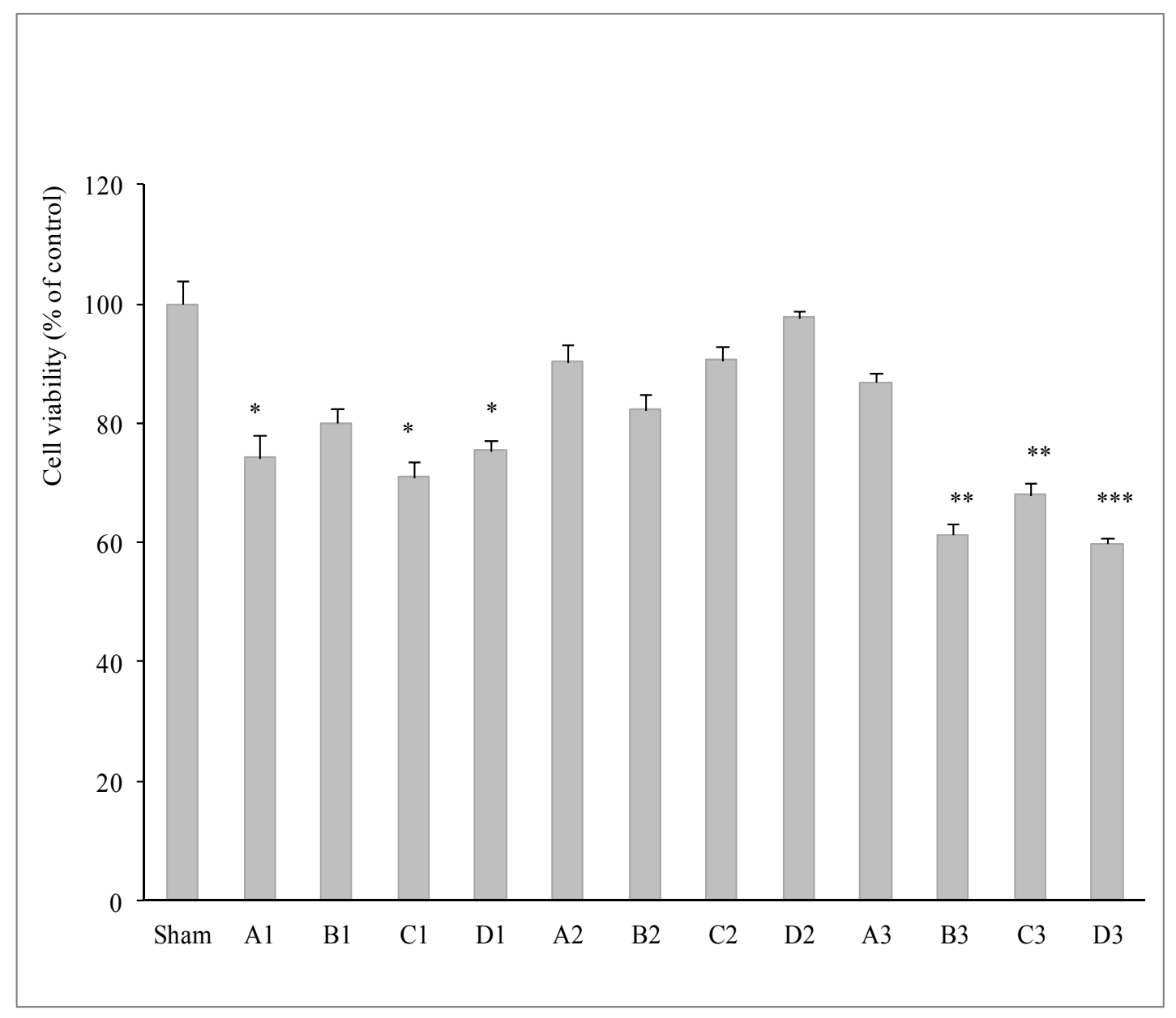

Figure 2. Percentage of viability $\pm \mathrm{SD}$ in $\mathrm{H} 727$ exposed at $70 \mu \mathrm{g} / \mathrm{mL}$ of environmental solutions for $6 \mathrm{~h}$ by MTT assay. $\mathrm{A}=$ Fraction $2.5-10 \mu \mathrm{m} ; \mathrm{B}=$ Fraction $1-2.5 \mu \mathrm{m}$; $\mathrm{C}=$ Fraction $0.5-1 \mu \mathrm{m} ; \mathrm{D}=0.25-0.5 \mu \mathrm{m}$. Site $1=$ platform; Site $2=$ commercial-intermediate area; Site 3 = outdoor. ${ }^{*} p<0.05,{ }^{* *} p<0.01,{ }^{* * *} p<0.001$ vs. untreated cells (Sham).

No statistically significant difference was observed in cells treated with samples from the commercial- intermediate area, nor in fraction B from samples taken on the platform and in outdoor fraction A.

\subsubsection{ROS Analysis}

The results of fluorimetric determinations of intracellular ROS production induced by particulate matter solutions are reported in Figure 3. After $3 \mathrm{~h}$ of contact with PM solutions, ROS were seen to have increased more markedly in samples treated with fractions $A(2.5-10 \mu \mathrm{m})$ and $\mathrm{B}(1-2.5 \mu \mathrm{m})$ from all three sampling sites.

The emission of DCF at the doses tested was approximately 4-fold higher in samples A1, A2, A3 and B1 than in Sham $(p<0.001)$ and approximately 3-fold higher when the cells were exposed to PM solution containing B2 and B3 $(p<0.001)$ in comparison with Sham. 


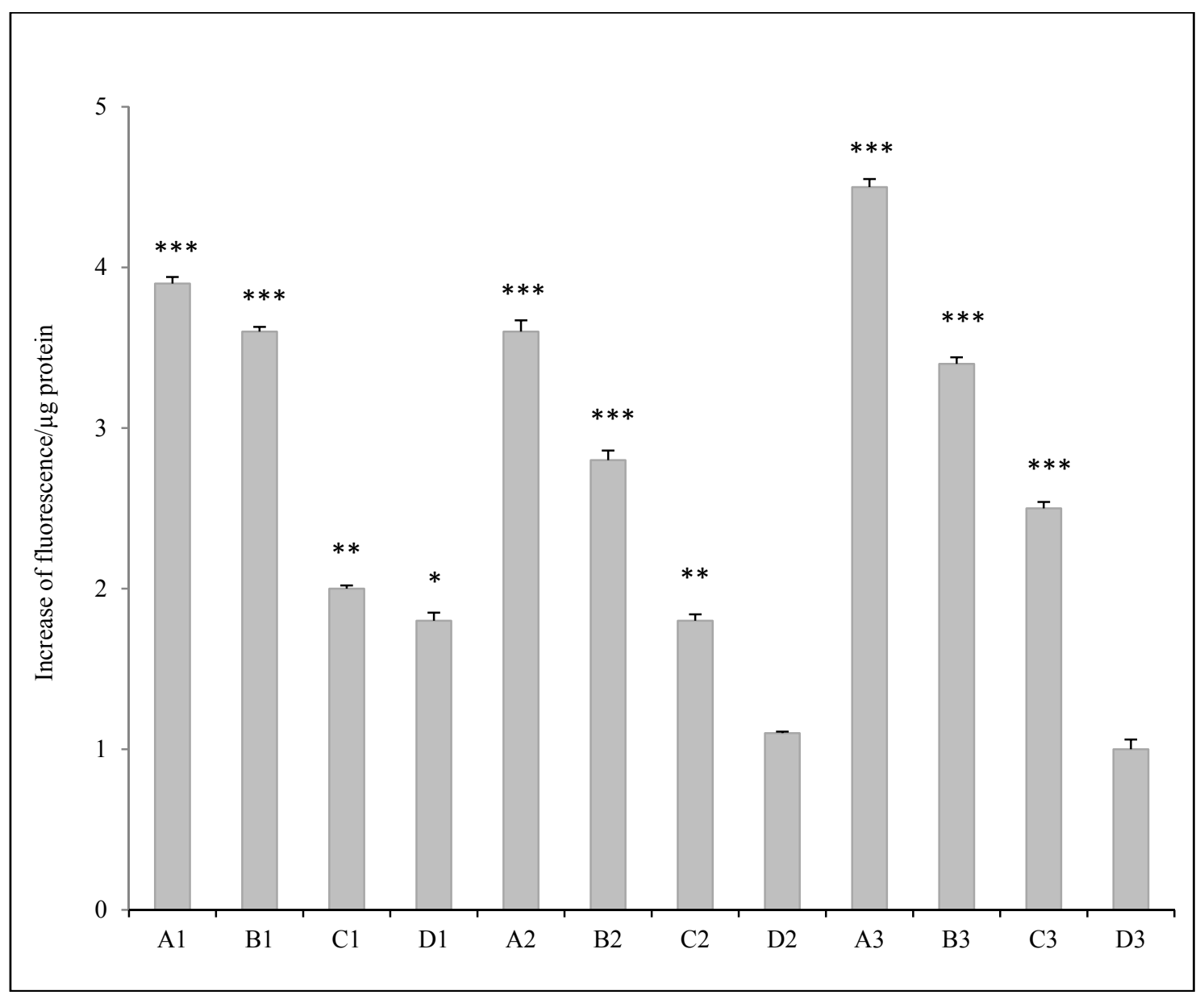

Figure 3. ROS expression in $\mathrm{H} 727$ cells treated for $3 \mathrm{~h}$, with different environmental solution. $\mathrm{A}=$ Fraction $2.5-10 \mu \mathrm{m} ; \mathrm{B}=$ Fraction $1-2.5 \mu \mathrm{m} ; \mathrm{C}=$ Fraction $0.5-1 \mu \mathrm{m}$; $\mathrm{D}=0.25-0.5 \mu \mathrm{m}$. Site $1=$ platform; Site $2=$ commercial-intermediate area; Site $3=$ outdoor. ${ }^{*} p<0.05,{ }^{* *} p<0.01,{ }^{* * *} p<0.001$ vs. untreated cells (Sham).

Solutions containing fractions $\mathrm{C}(0.5-1 \mu \mathrm{m})$ and $\mathrm{D}(0.25-0.5 \mu \mathrm{m})$ from Site 1 , when inoculated into the cellular substrate, increased DCF emission approximately 2-fold in comparison with Sham $(p<0.01)$. No significant change in fluorescence emission intensity was observed when cells were exposed to PM solutions of PM $<0.25 \mu \mathrm{m}$, with the exception of cells treated with solution D1, which increased fluorescence emission intensity 1.8-fold in comparison with Sham $(p<0.05)$.

From our assessment of the possible correlation between the metals contained in PM and ROS generation, it emerged that the concentrations of transition metals were correlated with increased oxidative capacity. Highly positive correlations were observed between ROS measurements and Mn $($ rho $=0.8898 ; p<0.001), \mathrm{Cr}(\mathrm{rho}=0.9014, p<0.001), \mathrm{Ti}(\mathrm{rho}=0.8531, p<0.001), \mathrm{Fe}(\mathrm{rho}=0.8112$, $p<0.01), \mathrm{Cu}($ rho $=0.7203, p<0.01)$ and $\mathrm{Zn}($ rho $=0.7552, p<0.01)$. Moreover, a consistent correlation was observed with levels of $\mathrm{Ni}(\mathrm{rho}=0.6033, p<0.05)$ and $\mathrm{Mo}(\mathrm{rho}=0.5783, p<0.05)$.

\section{Discussion}

Unlike other indoor environments, underground railway systems display unique features, in that they are enclosed spaces in which particulate matter emissions are particularly abundant, owing to the transit of trains and passengers [25]. These particles tend to accumulate and may reach high concentrations. 
Many people spend considerable time in underground railway systems every day. For instance, it has been estimated that in Helsinki about 100,000 people use the underground railway daily and that the average time spent travelling and/or waiting in this environment amounts to about 30 min per person per day [10]. Moreover, many urban railway systems, and indeed underground urban areas in general, host premises for public services and commercial activities, which are frequented by both members of the public and the staff who work in them.

Various studies, especially in recent years, have been aimed at evaluating pollution due to particulates in underground railway systems [8,26,27] and have documented higher concentrations than in outdoor environments.

In our study, the concentrations of both $\mathrm{PM}_{10}$ and $\mathrm{PM}_{2.5}$ proved to be similar at the three sampling sites: platform, commercial-intermediate area and street level. Moreover, at Site 1 (platform), these values were much lower than those found in other studies. A possible explanation for this difference lies in the fact that the level of pollution in underground railway systems is influenced by several factors, such as the age of the system (higher concentrations generally being recorded in older stations), the frequency of trains, the braking systems utilized, the daily number of passengers, etc. [28].

The particulate matter found in underground railway systems is a complex mixture of particles with high concentrations of Fe and other metals [10]. These metals may originate from outdoor sources and be carried into the underground system by air currents. However, the fact that some metals have been found in higher concentrations in underground environments than outdoors, in various studies [13,29,30] including ours, indicates that some of them are generated in loco, e.g., by the friction of the wheels on the rails and the wear of the brakes, etc. [29].

Iron in particular is regarded as characteristic of the particulate matter found in underground systems [10,13,31]; in such environments, iron-containing particles are chiefly generated by mechanical wear and tear and friction at the wheel-rail and wheel-brake interfaces and between the pantograph and the overhead cables. These processes initially produce particles of metallic iron, which, on reacting with the oxygen present in the air, are transformed into iron oxide.

In an analysis of $\mathrm{PM}_{10}$ in the Rome underground railway system, Ripanucci et al. [8] found that iron and silica were the main components of the particulate matter. Moreover, in a study conducted in the London Underground by Seaton et al. [7], it emerged that $67 \%$ of the $\mathrm{PM}_{2.5}$ collected was made up of iron oxides, while quartz and other metals accounted for $1 \%-2 \%$ and the remainder was composed of volatile substances.

In our study, iron was found to be present in greater amounts in the coarse fraction of the particulate matter than in the other fractions $\left(545.34 \mathrm{ng} / \mathrm{m}^{3} V s .212 .01 \mathrm{ng} / \mathrm{m}^{3}\right.$ in fraction $\mathrm{B}, 70.79 \mathrm{ng} / \mathrm{m}^{3}$ in fraction $\mathrm{C}$ and $30.54 \mathrm{ng} / \mathrm{m}^{3}$ in fraction D). Moreover, in each of the four fractions, with the exception of the smallest (D), iron displayed a greater concentration at Site 1 (platform) than at the other two sites. Iron also proved to be the most represented of the transition metals sought, not only at the platform level but also at the other sites monitored.

With regard to the underground commercial area situated at an intermediate level between the platform and the street, as mentioned above, the concentration of iron displayed an intermediate value between those recorded at the platform and street levels in all fractions with the exception of $\mathrm{D}$. The same trend was also observed in the total concentration of transition metals. 
For what concerns the crustal elements considered $(\mathrm{Ca}, \mathrm{Ba}, \mathrm{Al}, \mathrm{Mg}, \mathrm{K})$, the highest concentration recorded was that of calcium in the course fraction A collected at platform level $\left(1568.17 \mathrm{ng} / \mathrm{m}^{3}\right)$. As observed in other studies, the calcium detected at platform level could be carried in from outside by air currents. Alternatively, it might originate from construction work inside the underground itself, or from braking systems, etc. $[14,15]$.

Our results showed that total calcium concentrations (i.e., considering all fractions together) were about 4-fold higher at the level of the platform than at the intermediate-level and outdoor sites. This seems to suggest that this element is mainly produced in situ.

Indeed, particles containing iron and calcium are known to be generated by friction between the brake-pads, which are made of $\mathrm{CaCO}_{3}$, and the wheels of the train [14,30].

In order to assess the biological effects of particulate matter, several toxicological studies have recently been carried out [7,17,32]. A study conducted by Janssen et al. [33] used various tests, such as DTT assay and ESR assay among others, to determine the oxidative capacity of airborne PM collected at various sites (an underground railway system and several outdoor environments including an area of intense particular traffic). These authors found that the oxidative capacity of PM was far greater in the underground system than at the outdoor sites.

Similarly, Kam et al. [13] recorded a higher level of oxidative stress in particulate matter from an underground railway system than in particulates from an outdoor urban environment $(65 \%)$ and an overground railway (55\%). Metals such as $\mathrm{Fe}, \mathrm{Ni}, \mathrm{Cr}$ and $\mathrm{Cd}$ have been shown to display a strong correlation with ROS activity [6,34]. Karlsson et al. [23] demonstrated that airborne particulate matter in underground railway systems have a 4-fold greater ability to cause oxidative stress and 8-fold greater genotoxicity than particulates present in outdoor environments, and that this oxidative capacity is essentially due to the redox activity of these metals.

Several epidemiological studies have revealed that exposure to atmospheric PM is a risk factor for various pathologies, including tumours. These effects have chiefly been ascribed to the finest particulate matter (i.e., diameter $<2.5 \mu \mathrm{m}$ ) [35,36]. By contrast, the results of our study indicate that it is the coarse fraction $\mathrm{A}$ and sub-fraction $\mathrm{B}$ of the fine particulate matter which are associated with the greatest intensity of oxidative stress. Moreover, this intensity progressively declined as particle diameter diminished, as was revealed after the fine particulate matter had been broken down into sub-fractions.

The declining trend in ROS concentration as particle diameter diminished is similar to the behavior of the majority of the transition metals considered in our study, including those which are recognized as being particularly able to generate free radicals, such as $\mathrm{Fe}, \mathrm{Mn}, \mathrm{Cr}$ and $\mathrm{Cu}$ [29,35,37-39]. Indeed, the highest concentrations of transition metals - iron, chromium and others-were found in A and B fractions; their abundance would create an optimum condition in which to trigger a Fenton reaction, thus confirming the high oxidative potential of these samples.

Although underground commercial premises in stations are very common, they have, as far as we know, rarely been studied from the cytotoxicity standpoint. From the results of our study, it emerged that all particulate matter fractions, with the exception of fraction $\mathrm{D}$, displayed lower ROS values than the particulates collected at platform level or in the outdoor, street-level environment. 


\section{Conclusions}

The present study revealed that the underground railway environment at platform level, although containing higher concentrations of some particularly reactive metallic species ( $\mathrm{Fe}, \mathrm{Cr}, \mathrm{Mn}$, etc.), did not display higher levels of cytotoxicity and oxidative stress than the outdoor air. This would seem to suggest that the difference in the concentrations of transition metals between the platform and the outdoor environment was unable to induce a difference in terms of oxidative stress. The concentrations of $\mathrm{PM}_{10}$ and $\mathrm{PM}_{2.5}$ proved to be similar at the three sampling sites. Moreover, the values recorded at platform level proved to be far lower than those reported in other studies.

We monitored the commercial-intermediate area because of the long exposure times of staff and customers to any airborne pollutants present at this site. The particulate matter collected was seen to have less ability to induce oxidative stress than that gathered from the other two sites, with the exception of fraction $\mathrm{D}$, which proved comparable to that of the outdoor environment.

As fine particulates were broken down into sub-fractions, we were able to detail their chemical composition and behavior in terms of oxidative stress as a function of size. Moreover, the present research also explored an environment that has rarely been investigated, namely, an underground commercial area.

The results obtained are preliminary and will need to be confirmed by prolonging sampling times, collecting more samples at each site and increasing the number of chemical elements considered. Furthermore, in order to shed further light on the potential healthcare risk to subjects exposed to airborne particulate matter in the underground railway environment, further cytogenotoxicity studies will be required.

\section{Acknowledgments}

Financial support. This study was supported by the Italian Ministry of Education, Universities, and Research (project PRIN 2009ZTPMT7_004). We thanks the Laboratory of Environmental Genomics and Prevention of Chronic Degenerative Diseases-Department of Health Sciences of the University of Genoa for the collaboration and support to toxicity and ROS assessment and Marina Sartini for her assistance in the statistical analysis of the data.

\section{Author Contributions}

Maria Luisa Cristina conceived and designed the study and contributed to write the paper, Gianluca Ottria undertook the sample collection and performed analysis, Fernanda Perdelli undertook statistical analysis and interpretation of the data. Anna Maria Spagnolo supervised data collection and wrote the paper.

\section{Conflicts of Interest}

The authors declare no conflict of interest. The founding sponsors had no role in the design of the study; in the collection, analyses, or interpretation of data; in the writing of the manuscript, and in the decision to publish the results. 


\section{References}

1. Assimakopoulos, M.N.; Dounis, A.; Spanou, A.; Santamouris, M. Indoor air quality in a metropolitan area metro using fuzzy logic assessment system. Sci. Total. Environ. 2013, 449, 461-469.

2. Heinrich, J.; Thiering, E.; Rzehak, P.; Krämer, U.; Hochadel, M.; Rauchfuss, K.M.; Gehring, U.; Wichmann, H.-E. Long-term exposure to $\mathrm{NO}_{2}$ and $\mathrm{PM}_{10}$ and all-cause and cause-specific mortality in a prospective cohort of women. Occup. Environ. Med. 2013, 70, 179-186.

3. Beelen, R.; Stafoggia, M.; Raaschou-Nielsen, O.; Andersen, Z.J.; Xun, W.W.; Katsouyanni, K.; Dimakopoulou, K.; Brunekreef, B.; Weinmayr, G.; Hoffmann, B.; et al. Long-term exposure to air pollution and cardiovascular mortality: An analysis of 22 European cohorts. Epidemiology 2014, 25, 368-378.

4. Pope, C.A., 3rd; Burnett, R.T.; Thun, M.J.; Calle, E.E.; Krewski, D.; Ito, K.; Thurston, G.D. Lung cancer, cardiopulmonary mortality, and long-term exposure to fine particulate air pollution. JAMA 2002, 287, 1132-1141.

5. Langrish, J.P.; Mills, N.L. Air pollution and mortality in Europe. Lancet 2014, 383, 758-760.

6. Karlsson, H.L.; Holgersson, A.; Möller, L. Mechanisms related to the genotoxicity of particles in the subway and from other sources. Chem. Res. Toxicol. 2008, 21, 726-731.

7. Seaton, A.; Cherrie, J.; Dennekamp, M.; Donaldson, K.; Hurley, J.F.; Tran, C.L. The London underground: Dust and hazards to health. Occup. Environ. Med. 2005, 62, 355-362.

8. Ripanucci, G.; Grana, M.; Vicentini, L.; Magrini, A.; Bergamaschi, A. Dust in the underground railway tunnels of an Italian town. J. Occup. Environm. Hyg. 2006, 3, 16-25.

9. Johansson, C.; Johansson, P.A. Particulate matter in the underground of Stockholm. Atmos. Environ. 2003, 37, 3-9.

10. Aarnio, P.; Yli-Tuomi, T.; Kousa, A.; Mäkela, T.; Hirsikko, A.; Hämeri, K.; Räisänen, M.; Hillamo, R.; Koskentalo, T.; Jantunen, M. The concentrations and composition of and exposure to fine particles $\left(\mathrm{PM}_{2.5}\right)$ in the Helsinki subway system. Atmos. Environ. 2005, 39, 5059-5066.

11. Adams, H.S.; Nieuwenhuijsen, M.J.; Colvile, R.N. Determinants of fine particle (PM2.5) personal exposure levels in transport microenvironments, London, UK. Atmos. Environ. 2001, 35, 4557-4566.

12. Salma, I.; Weidinger, T.; Maenhaut, W. Time-resolved mass concentration, composition and sources of aerosol particles in a metropolitan underground railway station. Atmos. Environ. 2007, $41,8391-8405$.

13. Kam, W.; Ning, Z.; Shafer, M.M.; Schauer, J.J.; Sioutas, C. Chemical characterization and redox potential of coarse and fine particulate matter (PM) in underground and ground-level rail systems of the Los Angeles Metro. Environ. Sci. Technol. 2011, 45, 6769-6776.

14. Sitzmann, B.; Kendall, M.; Watt, J.; Williams, I. Characterisation of airborne particles in London by computer-controlled scanning electron microscopy. Sci. Total Environ. 1999, 241, 63-73.

15. Kang, S.; Hwang, H.; Park, Y.; Kim, H.; Ro, C. Chemical compositions of subway particles in Seoul, Korea determined by a quantitative single particle analysis. Environ. Sci. Technol. 2008, 42, 9051-9057. 
16. Jung, H.J.; Kim, B.; Malek, M.A.; Koo, Y.S.; Jung, J.H.; Son, Y.S.; Kim, J.C.; Kim, H.; Ro, C.U. Chemical speciation of size-segregated floor dusts and airborne magnetic particles collected at underground subway stations in Seoul, Korea. J. Hazard. Mater. 2012, 213-214, 331-340.

17. Jung, M.H.; Kim, H.R.; Park, Y.J.; Park, D.S.; Chung, K.H.; Oh, S.M. Genotoxic effects and oxidative stress induced by organic extracts of particulate matter ( $\left.\mathrm{PM}_{10}\right)$ collected from a subway tunnel in Seoul, Korea. Mutat. Res. 2012, 749, 39-47.

18. Adams, H.S.; Nieuwenhuijsen, M.J.; Colvile, R.N.; McMullen, M.A.; Khandelwal, P. Fine particle $\left(\mathrm{PM}_{2.5}\right)$ personal exposure levels in transport microenvironments, London, UK. Sci. Total Environ. 2001, 279, 29-44.

19. Lippmann, M. Toxicological and epidemiological studies of cardiovascular effects of ambient air fine particulate matter $\left(\mathrm{PM}_{2.5}\right)$ and its chemical components: Coherence and public health implications. Crit. Rev. Toxicol. 2014, 44, 299-347.

20. Cavallo, D.; Ursini, C.L.; Maiello, R.; Apostoli, P.; Catalani, S.; Ciervo, A.; Iavicoli, S. Genotoxic and oxidative effects induced on A549 cells by extract of $\mathrm{PM}_{10}$ collected in an electric steel plant. Acta. Biomed. 2008, 79, 87-96.

21. Lodovici, M.; Bigagli, E. Oxidative stress and air pollution exposure. J. Toxicol. 2011, doi:10.1155/2011/487074.

22. Akhtar, U.S.; Rastogi, N.; McWhinney, R.D.; Urch, B.; Chow, C.W.; Evansa, G.J., Scott, J.A. The combined effects of physicochemical properties of size-fractionated ambient particulate matter on in vitro toxicity in human A549 lung epithelial cells. Toxicol. Rep. 2014, 1, 145-156.

23. Karlsson, H.; Nilsson, L.; Möller, L. Subway particles are more genotoxic than street particles and induce oxidative stress in cultured human lung cells. Chem. Res. Toxicol. 2005, 18, 19-23.

24. Shuka, A.; Timblin, C.; BeruBe, K.; Gordon, T.; McKinney, W.; Driscoll, K.; Vacek, P.; Mossman, B.T. Inhaled particulate matter causes expression of Nuclear Factor (NF)-kB-Related genes and oxidant-dependent NFkB activation in vitro. Am. J. Respir. Cell. Mol. Biol. 2000, 23, $182-187$.

25. Jung, H.J.; Kim, B.; Ryu, J.; Maskey, S.; Kim, J.C.; Sohn, J.; Ro, C.U. Source identification of particulate matter collected at underground subway stations in Seoul, Korea using quantitative single-particle analysis. Atmos. Environ. 2010, 44, 2287-2293.

26. Kim, K.Y.; Kim, Y.S.; Roh, Y.M.; Lee, C.M.; Kim, C.N. Spatial distribution of particulate matter $\left(\mathrm{PM}_{10}\right.$ and $\left.\mathrm{PM}_{2.5}\right)$ in Seoul Metropolitan Subway stations. J. Hazard. Mat. 2008, 154, 440-443.

27. Murruni, L.G.; Solanes, V.; Debray, M.; Kreiner, A.J.; Davidson, J.; Davidson, M.; Vázquez, M.; Ozafrán, M. Concentrations and elemental composition of particulate matter in the Buenos Aires underground system. Atm. Environ. 2009, 43, 4577-4583.

28. Midander, K.; Elihn, K.; Wallén, A.; Belova, L.; Karlsson, A.K.; Wallinder, I.O. Characterisation of nano- and micron-sized airborne and collected subway particles, a multi-analytical approach. Sci. Total Environ. 2012, 427-428, 390-400.

29. Chillrud, S.N.; Grass, D.; Ross, J.M.; Coulibaly, D.; Slavkovich, V.; Epstein, D.; Sax, S.N.; Pederson, D.; Johnson, D.; Spengler, J.D.; Kinney, P.L.; Simpson, H.J.; Brandt-Rauf, P. Steel dust in the New York City subway system as a source of manganese, chromium, and iron exposures for transit workers. J. Urban. Health. 2005, 82, 33-42. 
30. Byeon, S.H.; Willis, R.; Peters, T.M. Chemical characterization of outdoor and subway fine (PM2.5-1.0) and Coarse (PM10-2.5) Particulate Matter in Seoul (Korea) by Computer-Controlled Scanning Electron Microscopy (CCSEM). Int. J. Environ. Res. Public. Health. 2015, 12, 2090-2104.

31. Kim, C.H.; Yoo, D.C.; Kwon, Y.M.; Han, W.S.; Kim, G.S.; Park, M.J.; Kim, Y.S.; Choi, D. A study on characteristics of atmospheric heavy metals in subway station. Toxicol. Res. 2010, 26, $157-162$.

32. Alessandria, L.; Schilirò, T.; Degan, R.; Traversi, D.; Gilli, G. Cytotoxic response in human lung epithelial cells and ion characteristics of urban-air particles from Torino, a northern Italian city. Environ. Sci. Pollut. Res. Int. 2014, 21, 5554-5564.

33. Janssen, N.A.; Yang, A.; Strak, M.; Steenhof, M; Hellack, B.; Gerlofs-Nijland, M.E.; Kuhlbusch, T.; Kelly, F.; Harrison, R.; Brunekreef, B.; Hoek, G.; Cassee, F. Oxidative potential of particulate matter collected at sites with different source characteristics. Sci. Total Environ. 2014, 472, $572-581$.

34. Risom, L.; Møller, P.; Loft, S. Oxidative stress-induced DNA damage by particulate air pollution. Mutat. Res. 2005, 592, 119-137.

35. Mugica-Álvarez, V.; Figueroa-Lara, J.; Romero-Romo, M.; Sepúlveda-Sánchez, J.; López-Moreno, T. Concentrations and properties of airborne particles in the Mexico City subway system. Atmos. Environ. 2012, 49, 284-293.

36. Longhin, E.; Holme, J.A.; Gutzkow, K.B.; Arlt, V.M.; Kucab, J.E.; Camatini, M.; Gualtieri, M. Cell cycle alterations induced by urban $\mathrm{PM}_{2.5}$ in bronchial epithelial cells: Characterization of the process and possible mechanisms involved. Part. Fibre. Toxicol. 2013, 10, doi:10.1186/1743-8977-10-63.

37. Dixon, S.J.; Stockwell, B.R. The role of iron and reactive oxygen species in cell death. Nat. Chem. Biol. 2014, 10, 9-17.

38. Tao, F.; Gonzalez-Flecha, B.; Kobzik, L. Reactive oxygen species in pulmonary inflammation by ambient particulates. Free Radic. Biol. Med. 2003, 35, 327-340.

39. Valavanidis, A.; Fiotakis, K.; Thomais, V. Airborne particulate matter and human health toxicological assessment and importance of size and composition of particles for oxidative damage and carcinogenic mechanisms. J. Environ. Sci. Health C Environ. Carcinog. Ecotoxicol. Rev. 2008, 26, 339-362.

(C) 2015 by the authors; licensee MDPI, Basel, Switzerland. This article is an open access article distributed under the terms and conditions of the Creative Commons Attribution license (http://creativecommons.org/licenses/by/4.0/). 